\title{
Impact of Public Intervention on Poor in Odisha: Special Focus on Pradhan Mantri Jan-Dhan Yojana
}

\author{
Namita Swain, Ajay Jain
}

\begin{abstract}
The establishment of Regional Rural Banks, cooperative societies, primary agricultural societies and introduction of priority sector credit guidelines are some of the state led initiatives which predominantly played an important role to develop a better scenario for the upliftment of the poor and weaker people in the country associated with agricultural sector and other allied sectors. But over the years it has been suggested in various literatures that the core aim of this type of financial inclusion may not be able to uplift the livelihood of the poor to an appreciable extent. This present paper evaluates the effects of PMJDY (nation-wide financial inclusion scheme) in the state of Odisha, and the results are being normalized for four different district the detail of which is mentioned in the below given matter. Study is based on primary data and the number of samples is 200 i.e. 50 from each district. The results are evaluated using one way ANOVA.
\end{abstract}

Keywords : Financial Inclusion, PMJDY, Odisha.

\section{INTRODUCTION}

Indian banking sector has a rich history and heritage. Banking is a business in financial intermediation where one group of people deposits money with the bank and other group utilize the same money by availing loan from the bank for income generating activities. The growth of an economy largely depends on the level of economic development. The performance of the financial sector adds value in terms of overall economic growth that a country aims at. Traditionally, the role of banking sector was restricted to provide finance to the needy sectors but lack of access to the finance sectors often created obstacles for the desired growth level. In most of the developing countries, access to finance is a problem. The banking system provides a cash management system to its customers in the form of various services. People have confidence in banks and therefore they deposit their hard earned money in banks. With changing demand of the customers, the product offerings of banks have also seen lots of changes. Thus along with dispensation of credit and deposit taking services, the banks have also started providing other major financial products like insurance, mutual funds, shares etc. so as to increase their reach and meet the growing demand of customers. Technology also started playing an important role so as to provide better value added services to

Revised Manuscript Received on September 15, 2019.

* Correspondence Author

Namita Swain, Research Scholar,SRMIST

Dr Ajay Jain, Assistant Prof.,SRMIST its customers.

\section{INCLUSION OF PEOPLE IN THE FINANCIAL DRIVE}

This is quite old in India but it has changed its nature and dimensions at different phases in the past. The establishment of Regional Rural Banks, cooperative societies, primary agricultural societies and introduction of priority sector credit guidelines are some of the state led initiatives which predominantly played an important role to develop a better scenario for the upliftment of the poor and weaker people in the country associated with agricultural sector and other allied sectors. But over the years it has been suggested in various literatures that the core aim of this type of financial inclusion may not be able to uplift the livelihood of the poor to an appreciable extent. So, time has come to think about a new approach to implement the financial inclusion programs. A paradigm shift can be expected as the very nature of the inclusion may change considerably over a period of time. Today, the inclusion is not restricted to any one sector; rather it targets human beings as a whole as part of the financial inclusion programs. As most of the people are moving away from traditional farming activities to other jobs both in organized as well unorganized sectors, time has come to examine critically the rationality of providing credit only to agricultural sector at a subsidized rate. Other emerging sectors can become part of that where prospects of income generating opportunities are more. Thus the concept of financial inclusion can be defined as access to wide range of financial products at a reasonable cost. These financial products can be in the form of all types of banking products, insurance products, mutual funds, pension products, equity etc. The changing nature of households started exploring various alternatives. The initiatives, like financial literacy programs also will be able to make the transition of the rural poor smooth.

\section{PMJDY CONCEPTUAL BACKGROUND}

Since independence, India has been witnessing introduction of lots of schemes for the benefits of poor or socially deprived groups. Policy makers also, gave too much emphasis on a particular group of people or sector. But the schemes failed to deliver as they were suffering from operational deficiencies starting from idea generation to implementation. As a result, the conditions of the beneficiaries did not improve significantly. The most crucial 
decision taken for the development of the backward classes was related to providing financial access to poorest of the poor. The plan of financial inclusion was conceived and commenced when the government first nationalized 14 big banks in 1969 so that they can be utilized as vehicle to provide credits to priority sectors, mainly agricultural and other neglected sectors. As Indian economy was heavily dependent on agricultural sector, the movement of subsidized credit to this sector was justified. But, the sector has received subsidized credit only. During these years, the sector failed to attract commercial farming using technology and other value added inputs. Traditional nature of the productive activities made the sector unprofitable. But even after so many initiatives, the socio economic condition of both the rural and urban poor has still not improved. Rather it has deteriorated substantially in view of open market operations. The priority sector lending, cooperative banks, regional rural banks, NABARD and microfinance institutions (MFIs) have all failed to produce any kind of social or economic upliftment. As the data reveals, still $40 \%$ of the rural households are borrowing from local money lenders. This surely can't be claimed as a success story for financial inclusion. Unlike other financial inclusion programmes, the objective here is not to cover the rural population only. It covers both rural as well as urban population. The push based strategy helped to move the things ahead. The major challenges as faced by the previous programs were to keep the accounts active. To deal with this issue the government has decided to link transfer of various direct benefit social welfare schemes with the accounts. As the target is not to cover any specific geographical area, the system is able to capture households who do not have bank accounts or access to any kind of financial services. The wide application of technology like RuPay debit card, mobile banking facilities, and e - KYC also helped the process to go smoothly. As there were monitoring problems in the previous programs, these facilities help to track the implementation properly.

\section{THE KEY BENEFITS OF THE PMJDY}

Credit plays an important part for any individual. Access to credit not only helps to improve the financial condition of the people; it also helps to get much needed capital for any kind of business activities. Lack of credit support will act negatively for the social and economic upliftment of the poor especially. Since lack of collateral and lack of own capital is one of the major constraints for the poor to access credit from formal financial organizations, they do not have other options but walk into the trap of local money lenders. Even after so many efforts from Government, most of the poor people are still borrowing from local money lenders. The PMJDY for the first time addressed this issue and incorporated the overdraft facility for these people so that they have access to credit as and when it is required by them. It may reduce his dependency on money lenders. Mobile Banking Facility The scheme has been designed with sophisticated technology which helps the users to access the bank accounts in their mobile. The new age technology will certainly help to implement the process of financial inclusion smoothly and it will become more user friendly. Since most of the poor people do not have the time to visit bank branches as they may lose their day's earnings, these facilities enable them to avail the services as and when the need arises. The mobile banking facilities are available on basic cell phones with SMS and USSD features. In a country where $40 \%$ of the population still remains unbanked, there is enough opportunity for banks to grow. The benefits of mobile banking facility can be witnessed in various other activities as well. The official figure says that Rs. 6745.41 crore has already been transferred in 18.9 crore transactions. This process helps to reduce the usage of subsidized cylinder in the open market and the benefits thus transferred to actual beneficiary. The real success of the program should not be restricted to opening of savings account only. The other important financial services like, pension, insurance, remittances etc. should also be included to expand the choice of the consumers. These value added services will definitely help to improve the future of the rural poor. The more they remain active; the more they will gain from it.

\section{Profile of the Study Area}

The PMJDY has been implemented in various parts of India. Some of the states have already achieved $100 \%$ target while some of the states are lagging behind. Like any other states of India, in Odisha also the project has been implemented in all the 30 districts. The block wise data of various districts of Odisha has shown the progress of PMJDY. But the progress is not uniform across the districts. In some of the district the progress is satisfactory while in some other districts the progress is not that satisfactory. For the present research purpose, a careful approach has been taken to identify four districts of Khordha, Nayagarh, Odisha, and Ganjam. Although the statistical result shows significant achievement, the ground level reality may be different. The reasons for choosing these two districts have been discussed in detail in the research methodology section of the study. In this section, a brief profile of the two districts has been given to get an overall understanding about the study area.

\section{LITERATURE REVIEW}

Khuntia (2014) The author discussed the importance of financial inclusion programme from the point of view of PMJDY. Because of immense contribution of various sectors, the country is growing and the growth is happening at the cost of rural and urban poor who are remaining financially excluded for a long period of time. These exclusions make them vulnerable. The negative impact of financial exclusion can be viewed in the lifestyle these people maintain. Lack of access to income generating opportunities, lack of skill development, lack of investment in education and healthcare and lack of flow of credit are the hallmarks of their lives

Sharma etal (2015) The identification of socially excluded people is very difficult as they are scattered around various parts of the country and their 
problems vary widely. Although India has been able to develop a proper mechanism to include the people who are financially excluded, geographical dispersion sometimes create difficulties to implement the same. Moreover, only providing finance will not be sufficient, effective monitoring of the same should also be taken into consideration. Unless and until the gap between demand and supply of credit is minimized, the existing problem may not be resolved.

Raval (2015) The author focuses on the issue of financial inclusion. The concept of financial inclusion is not new and it has gathered momentum with the introduction of PMJDY scheme. Since the success of the scheme entirely depends on its proper implementation and monitoring, the stakeholders have to work hard in this regard.

Shah etal (2015) The authors discussed the issue of financial inclusion and its trend. The financial inclusion programme which is a flagship programme of RBI was started much earlier. The objective was to provide financial services to the needy segment, which were otherwise treated as unbankable. Through financial benefits the poor people are now in a position to access the much needed capital to deploy for their economic growth.

\section{OBJECTIVE OF THE STUDY}

I. To study the scenario of exclusion from access to financial service.

II. To identify the barriers face by lower section in access of financial service.

\section{HYPOTHESIS OF THE STUDY}

\section{Hypothesis-1}

$\mathrm{H}_{0}$ : Principal and secondary benefits of bank accounts have no influence in the decision to open bank accounts under PMJDY.

$\mathrm{H}_{\mathrm{a}}$ : Principal and secondary benefits of bank accounts have an influence in the decision to open bank accounts under PMJDY.

\section{Hypothesis-2}

$\mathrm{H}_{0}$ : Financial Inclusion significantly impacts the poverty ratio in a multi-factor setting.

$\mathrm{H}_{\mathrm{a}}$ : Financial Inclusion significantly impacts the poverty ratio in a multi-factor setting.

\section{RESEARCH METHODOLOGY}

\section{Sources of Data}

Both essential and optional information are being utilized in the examination, where the essential information is gathered through close to home conveyance and mailing of surveys.

\section{Questionnaire and Sampling}

It is an instance of organized undisguised survey. The sorts of inquiries have been both shut and open sorts. The information was gathered through close to home conveyance and mailing of polls. The inquiries were surrounded by counseling driving bank officials, mentors and academicians.

\section{Statistical Tools}

Different scientific and factual instruments were utilized like rate, chi square and One Way ANOVA (F-Test).

\section{DATA ANALYSIS AND INTERPRETATION}

Table 1:Summary of ANOVA Results H 1

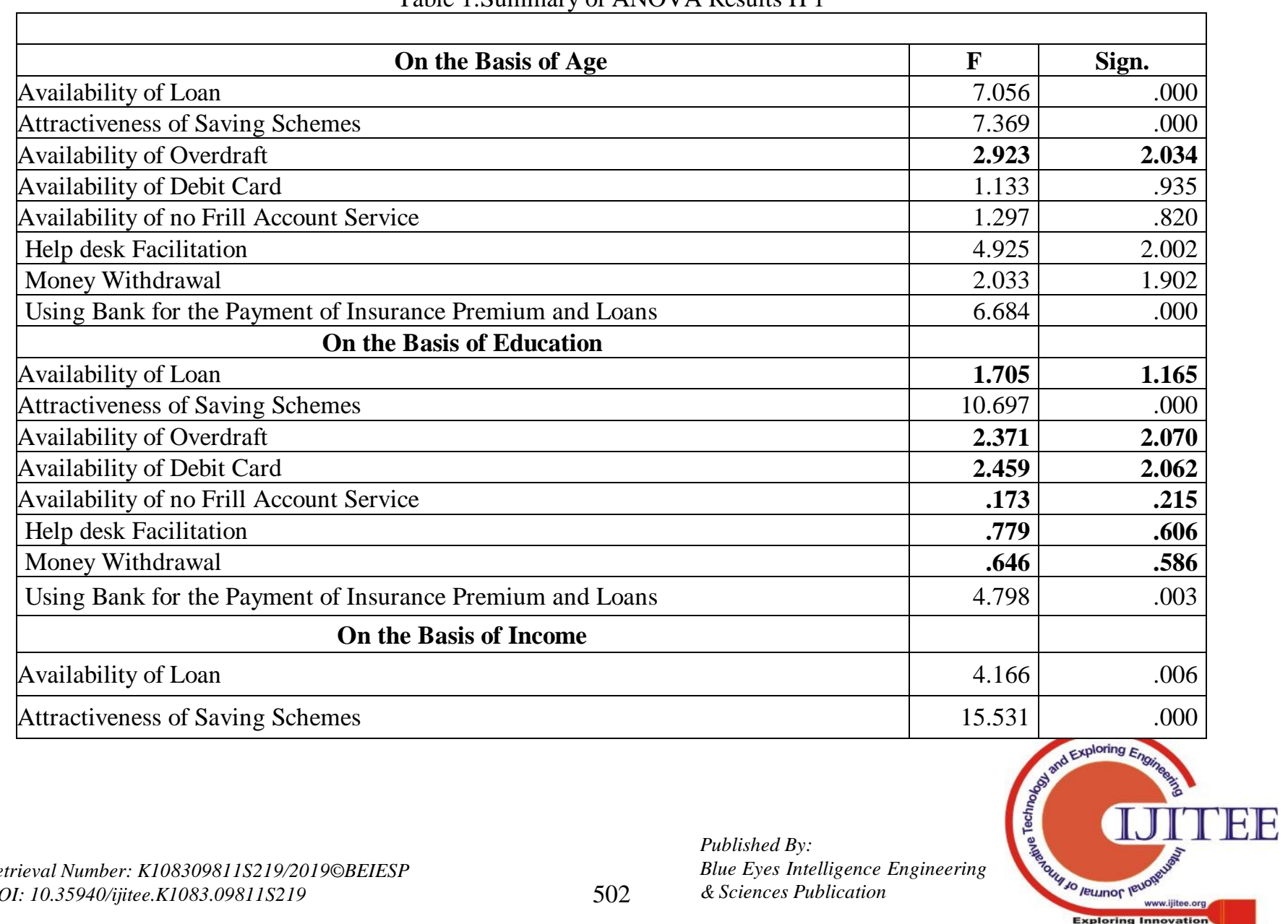


Impact of Public Intervention on Poor in Odisha: Special Focus on Pradhan Mantri Jan-Dhan Yojana

\begin{tabular}{|l|r|r|}
\hline Availability of Overdraft & 7.887 & .000 \\
\hline Availability of Debit Card & $\mathbf{4 . 5 3 7}$ & $\mathbf{4 . 0 0 4}$ \\
\hline Availability of no Frill Account Service & $\mathbf{. 3 1 6}$ & $\mathbf{. 4 1 4}$ \\
\hline Help desk Facilitation & 17.921 & .000 \\
\hline Money Withdrawal & $\mathbf{. 6 7 6}$ & $\mathbf{. 5 0 8}$ \\
\hline Using Bank for the Payment of Insurance Premium and Loans & $\mathbf{2 . 1 6 8}$ & $\mathbf{2 . 0 9 1}$ \\
\hline \multicolumn{1}{|c|}{ On the Basis of Marital Status } & & \\
\hline Availability of Loan & 3.445 & .017 \\
\hline Attractiveness of Saving Schemes & 14.360 & .000 \\
\hline Availability of Overdraft & 3.352 & .019 \\
\hline Availability of Debit Card & 4.508 & .004 \\
\hline Availability of no Frill Account Service & $\mathbf{. 5 1 0}$ & $\mathbf{. 6 7 6}$ \\
\hline Help desk Facilitation & 20.677 & .000 \\
\hline Money Withdrawal & 4.408 & .005 \\
\hline Using Bank for the Payment of Insurance Premium and Loans & $\mathbf{3 . 4 4 5}$ & $\mathbf{3 . 0 1 7}$ \\
\hline Availability of Loan & 14.360 & .000 \\
\hline
\end{tabular}

\section{Interpretation}

On the basis of age, the variation in the responses is comparable, i.e. in most of the cases the value of 'Sign' is almost adjacent to the value of ' $F$ ', this shows that as the age of the respondents increases they gain experience and come to know about various products of the banking system and having an account in the same they expect to have the access to all the available to products. But as a matter of fact this might not stand true for the accounts opened under PMJDY. As can be seen on the basis of education, in most of the cases there is minimum variation in the respective values of 'Sign.' and ' $F$ ', this indicates that people have some idea about the services offered in a bank to any of the given customer, and they also understand the limitation of the accounts opened under PMJDY.

Then comes the component of income and marital status, where it can be seen that in most of the cases the amount of variation is high in the responses of the sampling units, this shows that with the increase in the income of the respondents they require some more benefits from their respective banks and the facilities made available to the PMJDY account might not suit their requirements.

\section{Result}

In light of the above interpretation, it can be said that Principal and secondary benefits of bank accounts have some influence in the decision to open bank accounts under PMJDY, hence the null hypothesis is rejected and the alternate hypothesis is accepted.

\subsubsection{Hypothesis-2}

$\mathrm{H}_{0}$ : Barriers to financial inclusion have significant impact on the access and usage dimensions.

\section{$\mathrm{H}_{\mathrm{a}}$ : Barriers to financial inclusion do not have significant impact on the access and usage dimensions.}

Chi Square test on Gender, Education and income were applied to find the homogeneity of the respondents regarding the respective barriers and usage dimensions.

Table 2: Summary of Chi Square Test results H5

\begin{tabular}{|l|c|c|}
\hline \multicolumn{1}{|c|}{ On the Basis of Gender } & Calculated Value & Table Value \\
\hline Don't like dealing with banks & 3.677 & 0.159 \\
\hline No Bank will Open Account & 2.827 & .243 \\
\hline The Minimum Balance is too high & 1.421 & 0.562 \\
\hline Bank Hours are Not Convenient & 5.537 & 0.063 \\
\hline Do not have Enough Money & & 0.943 \\
\hline \multicolumn{1}{|c|}{ On the Basis of Education } & 2.860 & 0.631 \\
\hline Don't like dealing with banks & 6.145 & 0.703 \\
\hline No Bank will Open Account & 5.504 & 0.943 \\
\hline The Minimum Balance is too high & 2.860 & 0.339 \\
\hline Bank Hours are Not Convenient & 9.040 & \\
\hline Do not have Enough Money & & \\
\hline
\end{tabular}

Do not have Enough Money 


\begin{tabular}{|l|c|c|}
\hline \multicolumn{1}{|c|}{ On the Basis of Income } & & \\
\hline Don't like dealing with banks & 17.101 & 0.146 \\
\hline No Bank will Open Account & 10.473 & 0.575 \\
\hline The Minimum Balance is too high & 5.745 & 0.928 \\
\hline Bank Hours are Not Convenient & 16.353 & 0.176 \\
\hline Do not have Enough Money & 9.053 & 0.698 \\
\hline
\end{tabular}

This hypothesis evaluate the responses of the persons who do not have accounts in banks and are not the beneficiaries of PMJDY, the researcher had tried to find the reasons for this reluctant behavior of the respondents.

In all the above cases it can be seen that the calculated value is more than that of the table value, this shows that the respondents were not sure about the reason for which they are not willing to face the bank for their financial needs, apparently they have chosen the reasons from the alternative provided in the questionnaire, here it is important to mention that there are many of the respondents who are not educated and are of old age have shown faith in the scheme of PMJDY and today they are taking the benefits of the same.

\section{Result}

On the basis of above analysis and interpretation it can be stated that Barriers to financial inclusion have significant impact on the access and usage dimensions and the null hypothesis can be accepted and the alternate hypothesis can be rejected.

\section{CONCLUSION}

There is a moderate level of awareness about PMJDY. They also know the insides of the scheme like accidental insurance, life insurance etc. Which shows that the attempt made to spread its awareness among the general public of India was a success. Study reveals that people feel it's a wonderful step taken by the Govt. of India to launch this scheme which is beneficial for all and encourage saving habits among masses. This scheme will be beneficial to increase economic growth of the Nation and reduce poverty; also this scheme will prevent ignorant groups of the society to be exploited by the informal sources like money lenders. And awareness regarding this scheme is dependent on age group as the results shown by chi square test, which is also tallied by the responses regarding awareness.

Dealing with a financial balance and protection inclusion does not request the individual ought to be taught; it just required the essential information which could be clarified by any other person. Absolutely with a firm expectation and infrastructural system of establishments the fantasy of money related administrations for all can be acknowledged sooner rather than later.

\section{REFERENCES}

1. Mr.S. I. Malligar and Mr. B. Bankapur (2016) "Performance of Pradhan Mantri Jan-Dhan Yojana”, Indian Journal of Applied Research January, 2016.

2. Guha, Santana (2015) "The role of Pradhan Mantri Jan Dhan Yojana in Financial Inclusion- An Evaluative Study”, GJRA-Global Journal for Research Analysis July, 2015.

3. Hussain, Ahmed (2015) "Pradhan Mantri Jan Dhan Yojana: The most intensive Financial Inclusion scheme in India, International Journal of Core Engineering and Management (IJCEM).
4. Bhatia, S., \& Singh, S. (2015). FINANCIAL INCLUSION - A PATH TO SUSTAINABLE GROWTH. International Journal of Science Technology \& Management, 388-397.

5. Dasgupta, A., \& Anklesaria, E. (2015). Pradhan Mantri Jan Dhan Yojana. KPMG report.

6. Patel, A. (2015). Pradhan Mantri Jan DhanYojana : Need for a Strategic Action Plan . Pacific Business Review International , 110-112.

7. Verma, y. (2016). Pradhan Mantri Jan Dhan Yojana (PMJDY): A Step towards Eradicating Financial Untouchability. Indian Journal of Finance.

8. Mr.S. I. Malligar and Mr. B. Bankapur (2016) "Performance of Pradhan Mantri Jan-Dhan Yojana", Indian Journal of Applied Research January, 2016.

9. Harpreet Kaur and Kawal Nain Singh (2015) "Pradhan Mantri Jan Dhan Yojana (PMJDY): A Leap towards Financial Inclusion in India”, International Journal of Emerging Research in management and Technology.

10. Mr.S. I. Malligar and Mr. B. Bankapur (2016) "Performance of Pradhan Mantri Jan-Dhan Yojana”, Indian Journal of Applied Research January, 2016.

11. Harpreet Kaur and Kawal Nain Singh (2015) "Pradhan Mantri Jan Dhan Yojana (PMJDY): A Leap towards Financial Inclusion in India", International Journal of Emerging Research in management and Technology.

12. Rajanikanta Khuntia (2014) "Pradhan Mantri Jan Dhan Yojana (PMJDY): A New Drive towards Financial Inclusion in India", International Journal of Business Economics and Management Research.

13. Mr. Santana Guha (2015) "The role of Pradhan Mantri Jan Dhan Yojana in Financial Inclusion- An Evaluative Study”, GJRA-Global Journal for Research Analysis July, 2015

14. Ahmed Hussain (2015) "Pradhan Mantri Jan Dhan Yojana: The most intensive Financial Inclusion scheme in India, International Journal of Core Engineering and Management (IJCEM).

15. Shri Lakshmi and D. Mamatha and Dr. Ponniah V. M. (2014) "A study on Pradhan Mantri Jan Dhan Yojana-with reference to Nationalized bank (Bank of Baroda)", SAMZODHANA- Journal of Management Research.

16. Dr. Vinit Kumar, and Dolly Singh (2015) "PMJDY: A Conceptual Analysis and Inclusive Financing”, International Journal of Innovative Social Science and Humanities Research.

17. Hardeepika Singh Ahluwalia, Kulbir Kaur Bhatti,(2016) Financial Inclusion: A Comparative Study of Initiatives Taken by Indian Government Pre and Post 1991, The International Journal Of Business \& Management (ISSN 2321-8916), Vol 4 Issue 6.

18. Harpreet Kaur \&Kawal Nain Singh (2015), "Pradhan Mantri Jan DhanYojana (PMJDY): A Leap towards Financial Inclusion in India", International Journal of Emerging Research in Management \&Technology, Vol. 4 (1), pp. 25-29.

19. John d. Villasenor, Darrell m. West, and Robin j. Lewis (2015) ,"Financial and digital inclusion : measuring progress on digital access and usage", The Brooking Report

20. Poonam, Archna Chaudhry,(2016) Financial Inclusion in India: A State Level Study, SSRG International Journal of Economics and Management Studies (SSRG-IJEMS) - volume3 issue3, pp 67-68.

21. Suresh A, Dr. M. Srinivasa Narayana, Dr. P. Vijay Kumar, (2016) A Study on Financial Inclusion Initiatives and Challenges in India With Reference to PMJDY, IRA-International Journal of Management \& Social Sciences ISSN 2455-2267; Vol.03, Issue 03.

22. Dr. P. Sugunalakshmi and A. Rathina Maheswari, (2016), Consumer Durable Industry in India - Present Trend, Challenges and Future Prospects. International Journal of Management, 7(2), 2016, pp. 449-453.

23. Monica Gupta and Dr. Kavita Aggarwal, (2016), Prospects of Small Scale Industry In Punjab. International Journal of Management, 7(7), 2016, pp. 226-231. 